\title{
In Tune with the Listener: How Local Radio in Ireland has Maintained Audience Attention and Loyalty
}

\author{
Daithí McMahon ${ }^{\text {* }}$ \\ (iD) 0000-0003-3477-1156 \\ ${ }^{1}$ University of Derby, UNITED KINGDOM \\ * Corresponding author: d.mcmahon@derby.ac.uk
}

Citation: McMahon, D. (2021). In Tune with the Listener: How Local Radio in Ireland has Maintained Audience Attention and Loyalty. Online Journal of Communication and Media Technologies, 11(3), e202112. https://doi.org/10.30935/ojcmt/11085

\section{ARTICLE INFO}

Received: 10 Apr 2021

Accepted: 9 Jun 2021

\section{ABSTRACT}

Local radio has remained relevant and ever-present in Ireland owing to the relationship stations have built with their audiences over time. These strong connections combined with adherence to public service duties and supplying locally relevant content - which the national stations cannot offer - helped local stations repel the double threat of a global recession and the influx of new media. This paper argues that by building on its core strengths while embracing change and adopting the potential offered by digital and social media, local Irish commercial radio stations have managed to survive and remain relevant. Using case studies of two prominent stations Radio Kerry and Beat, and one public service station RTÉ 2fm, this paper will illustrate that by being in tune with the audience's unique social, cultural and political interests, radio stations have been able to endear their audiences to the brand and compete for their attention in an increasingly competitive mediascape. These stations were able to achieve this partly through the formation of online communities on Facebook, by having a presence in the local community and by actively engaging with the audience. This paper posits that local radio holds an important place in the lives of the people it serves and therefore must be preserved as not only an invaluable public service but as a beacon of culture and heritage.

Keywords: local radio, Irish Radio Industry, Facebook, Radio Kerry, Beat, online communities

\section{INTRODUCTION}

Radio has a special and important place in the hearts and minds of the Irish people as their constant companion. In Ireland, radio sets the agenda each day and acts as a public forum for a diverse range of topics that interest the audience. However, today radio is operating in an incredibly dynamic digital world where competition for time, attention and relevance in people's lives is at an all-time high. Though the Irish Radio Industry has always boasted a loyal audience, constant change is inevitable to modernise the medium and appeal to the next generation of listeners. As it changes, however, it must also remain true to its roots as an aural medium that connects people and helps them feel part of a shared experience within a community of like-minded listeners.

Radio's ability to connect with its audience and simultaneously be with listeners individually and collectively throughout the day makes for a unique mass medium with an advantage over its traditional rivals - television and daily periodicals. Local and regional radio also have an edge over their national competitors due to the bespoke nature of local programming and remit as disseminators of provincial news, information and cultural content (Starkey, 2011).

Meanwhile, Facebook supports, enhances and facilitates daily radio broadcasting and gives the audience opportunities to contribute to programmes while reinforcing communal sentiments (McMahon, 2019a). Since radio shares many similar characteristics with Social Network Sites (SNSs) - liveness, spontaneity, sense of community - the two media form a dynamic synergy. This coupling serves as an example of how radio has converged with new media almost seamlessly, given its flexibility and adaptability in service of its audience (McMahon, 2019a). Radio's ability to adapt so easily has been greatly advantageous for the old, predominantly 
analogue medium in Ireland's case (Ipsos MRBI, 2021b), in remaining relevant in a hyperactive, fragmented and congested mediascape. One of radio's greatest qualities is its ability to bring together people with shared cultural identities (Hilmes, 2007). This could include social and/or cultural attributes and tastes such as music (Douglas, 2004), which allow individuals to feel part of a community (Michelson et al., 2019) with members moving to the beat of the 'tribal drum' (McLuhan, 1994).

Radio has had to fight for relevance in an increasingly interconnected digital mediascape and local radio in Ireland has been particularly adept at using digital media for its own benefit. This article's author trained and worked in Irish local radio from 2007 and has studied industry developments in audience participation ever since. He was also an avid radio listener throughout this period and is coming at this from a media production perspective, working to understand the unique and often intimate relationship between a radio station and its audience members and conceptualising the local radio audience as members of imagined communities (Anderson, 1991).

Using Irish radio stations Radio Kerry and Beat 102103 (Beat) as case studies, this paper will show how these stations have maintained their independence in the face of severe economic and technological pressure, while making positive contributions to their respective broadcast regions in the process. The paper uses these examples to illustrate how the independent radio sector in Ireland more broadly survived the economic recession of 2008-2016, and is resisting the ever-present threat of media conglomeration, while remaining committed to its public service remit and reinforcing a communal ethos both on-air and online.

Furthermore, this paper illustrates how a local station's engagement with its audience via Facebook and other social media helps to draw the audience together through a shared sense of community - through heritage, culture and identity in the case of Radio Kerry; and a shared age demographic, culture and identity in the case of Beat. Facebook has proven effective in drawing people closer together to strengthen offline relationships while engendering feelings of unity and belonging among these audiences. The relationship has not been all positive however, as Facebook and the other digital giants have syphoned advertising spend away from indigenous media, including radio. Thus far Irish radio is maintaining audience loyalty and strong listener ratings and has staved off the rationalisation of the industry into fewer homogenised radio brands, as has occurred in the United Kingdom.

This paper posits that local and regional radio stations in Ireland are acutely cognisant of their audience's tastes, preferences and interests, and use numerous platforms to engage and build allegiance, and in the process, create something of a centripetal effect. In contrast, national stations are less successful at utilising a community-centric audience strategy, including the established and well-resourced public service broadcaster Raidió Teilifís Éireann (RTÉ).

\section{BACKGROUND \& CONTEXT - CHANGE FOR IRISH RADIO}

The Irish Radio Industry is broadly comprised of three sectors: the public service sector made up of RTÉ's four national stations; the independent commercial sector's 34 independent commercial stations (two national, one multi-city, four regional and 27 local) covering every county in the country; and the community sector with 22 not-for-profit special interest stations. All three sectors are regulated by the Broadcasting Authority of Ireland (BAI), with the latter two sectors operating on individual licences issued by the BAI. Ireland continues to rely heavily on FM broadcast and has thus far not developed its DAB infrastructure beyond the Dublin region (Ipsos MRBI 2021b). RTÉ has even recently decided to discontinue broadcasting in DAB (Crowley, 2021) leaving the future use of the broadcast technology in Ireland very much in doubt.

Thus far, the Irish Radio Industry has largely avoided the move towards a conglomerated industry where radio stations are folded into larger, regional, music-format entities as has been the case in the neighbouring UK (Waterson, 2020). In such a market the number of stations, and thus costs, notably news gathering and distribution, shrink while combined audience reach and profitability increase due to the wider attraction to advertisers (Starkey \& Crisell, 2009). These stations broadly claim to represent entire regions of the UK, or musical genres, with centralised news services that provide scant local news coverage and do little to represent the unique culture or identity of the regions they serve. Notable UK radio brands include Kiss and Capital which are owned by the dominant corporations Bauer Media and Global respectively. Hendy (2000) anticipated this concentration of ownership in the UK Radio Industry when radio was embarking on its digital 
transition at the turn of the millennium. The forces driving agglomeration were, and continue to be, fiscal. By 2009, half of all UK commercial radio stations were running at a loss (Radiocentre, 2009) and were thus exposed to take-over from larger corporations.

As local stations disappear there is an inevitable loss of engagement as local presenters are replaced by new voices dispensing generic and sporadic links from centralised studios. This is a far cry from the locally sourced and produced output previously offered that served the locality with bespoke content (Chignell, 2009). In a conglomerated radio industry speech programming is usually confined to a once daily breakfast and/or drivetime programme which is syndicated across a brand's network to reduce costs (Starkey, 2011). This restructuring leads to the recycling and homogenisation of radio content, the closure of small radio stations, particularly in rural areas with lower population densities, and the erosion of the quality of news gathering and reportage. This is due to the inevitable cuts to news room budgets and loss of local editorial control (McDonald \& Starkey, 2016).

The recent sale of Ireland's Communicorp to the European media giant Bauer Media (Slattery, 2021) would be cause for concern were it not for Ireland's competition laws that limit centralisation of media ownership. Bauer will thus have a limited stake in the industry. That said, an oligopoly could be slowly developing with Wireless Media, a UK media company, already having a strong stake in radio on the island of Ireland and RTÉ holding a healthy market share.

The fight against conglomeration will endure, and as the current pandemic wreaks havoc on commercial enterprise at all levels, local Irish radio stands to lose key advertising and sponsorship revenues as local businesses are forced to close. There are also wider factors to consider which are putting pressure on the commercial viability of the Irish Radio Industry's current funding model. Advertising spend has been quickly shifting away from old media (radio, TV and print) and towards new media. Facebook and Google are leading the way with an estimated 58\% of the advertising spend in 2017 and rising (McGee, 2018). These two organisations, with little or no interest in a competitive and sustainable Irish media market, could swallow the market whole at the current rate of growth. Social media is therefore a frenemy of radio - at once a friend and an enemy. As this paper illustrates, radio has benefitted from building better connections with its audience via SNSs, but the medium's demise has been accelerated by a diversion of the domestic advertising spend into the pockets of international digital advertising corporations. The broadcast media model is neither cost effective nor accurate, and thus not competitive nor fit for purpose in the modern global and digital media market.

Interestingly the situation is much different for Ireland's closest neighbour, the United Kingdom, where commercial radio continues to experience strong radio listenership of $89 \%$ of the population (RAJAR, 2020). Furthermore, the radio industry in the UK has enjoyed financial stability, with record advertising revenues in 2018 (Radiocentre, 2018). The big casualty has been local radio however, which has lost scores of stations in recent years (Waterson, 2020). Meanwhile, Irish radio remains relatively provincial in radio production and ownership. High production value, though appealing to small, local audiences is expensive to produce and largely attracts micro and small enterprises with limited advertising budgets as clientele. Despite a solid listener base, Irish radio listenership has been slowly shrinking over the past decade (Ipsos MRBI, 2011, 2021a). On average $81 \%$ of adults listen to the radio each day, with more than half (55\%) listening to their local or regional station and $43 \%$ to a national station (Ipsos MRBI, 2021a). The biggest battle is now over the future generations of radio listeners. Beat management is acutely aware of this and, with the proportion of young listeners aged 15-34 falling to 70\% this year, the fight to attract and retain young listeners will be arduous.

Social Network Sites (SNSs) grew in popularity and became a mainstay in modern Irish society in the past decade. The platforms, Facebook and Twitter predominantly, have been adopted eagerly by radio stations as a way of extending the station's brand and connecting with the audience. By adopting SNSs as audience participation tools the medium entered the digital age and in doing so has shaken off it's 'old medium' tag and has been reimagined as 'Radio 2.0' (McMahon, 2014). As a result, the modern radio audience has developed from a listener to an online media user which has had profound implications for stations and audiences alike and has shaped the course of the relationship between the two. 


\section{METHODOLOGY}

There were three radio stations included in this study, two commercial and one public service broadcaster (PSB). Radio Kerry is a 'full-service' commercial station serving all ages in county Kerry in the south-west of Ireland since 1990. The station describes a typical Radio Kerry listener "is aged between 25-65 and their main information requirements are current affairs, local news, sports, music, specialist speech programming and weather" (Radio Kerry, 2020). Beat 102103 (Beat) is a regional music and entertainment station aimed at the 15-34-year-old market covering five counties in the south-east region of Ireland. Beat describes itself as "a market leader among young adults across the region" (Beat, 2021). The station claims that it "outperforms its national rivals Today FM and [RTÉ] $2 \mathrm{fm}$ in both the All Adult and Under 35 market in the South East" (Beat, 2021). RTÉ $2 \mathrm{fm}$, is a music and entertainment station aimed at 20-40-year-olds. Based in Dublin but broadcasting nationally, it is the youth oriented public service radio station. Although Beat and Radio Kerry service separate franchise areas and thus are not in direct competition, both stations are in competition with $R T E ́ 2 f m$ and the other national broadcast services.

The quantitative and qualitative data sets for this study were gathered using a multimethod approach involving a questionnaire that was disseminated through Facebook and achieved 67 Radio Kerry, 99 Beat and 129 RTÉ $2 \mathrm{fm}$ respondents. The key findings from the survey used in this study relate to their perceptions of community on their radio station's Facebook page. Textual analysis was also conducted of each station's Facebook page on random dates. In-depth interviews were conducted with key staff at all three radio stations and their professional daily work practices observed to further inform the research. The research was conducted over the years 2011-2016 with a longitudinal content analysis, which measured the Facebook followers of each radio station over the first three years of that period, also carried out.

\section{LOCAL RADIO'S COMPETITIVE EDGE}

There are three areas in which local radio stations and their staff have been focusing their efforts and thus have an edge over the national competition. Firstly, by remaining focused on the primary product of on-air programming and maintaining consistently high standards of public service content. Secondly, by building and maintaining audience intimacy, knowledge and presence amongst them over time which endears the audience and draws them to the station. Thirdly, by creating on-air and online communities amongst the audience members where they feel a sense of belonging, a shared identity and affinity to the station.

\section{On-Air Content is King}

Each and every one of the professionals interviewed stressed the importance of the primary product, onair output, which must never be compromised or weakened. Any loss of focus on providing that consistent, trusted voice in people's everyday lives would be of the detriment to the entire station and its future. Local radio station management believe their greatest asset is their unparalleled intimacy with their audience, something local stations are able to create more easily than national stations. According to the Independent Broadcasters of Ireland (IBI), "radio is very much part of the community and has its finger on the pulse of what's happening and what's important to the listener" (IBI, 2014). Beat and Radio Kerry station managers argue that because they 'know their audience' and 'listen to them' they can thus offer a bespoke news and current affairs service that covers the local issues and topics that are of particular interest and importance to them. This is something RTÉ and the other national commercial stations cannot compete with at the same depth and detail.

Alongside quality programming, local radio's news and current affairs provision that reflect "the needs, interests and culture of the local community" (Chignell, 2009: p.132) is a strong attraction for listeners, with the medium considered the most-trusted source of news and information in Ireland (Reuters Institute, 2018). Chantler and Stewart also identified the value of local news, "In an increasingly competitive marketplace, news is one of the few things which makes a local station sound distinctive and 'close to you'"' (Chantler \& Stewart, 2003, p. 11). The most popular content amongst Irish radio audiences were, 'news, sport and travel information' 38.7\%, followed by 'music' 18.2\% and 'local news' 14.1\% (Core Media/Ignite 2013). These were consistent with the findings of the audience surveys which found news and information as the primary 
content sought from radio. Radio has traditionally been found to serve a valuable role as a provider of live, well-informed and reliable news and information (Hofstetter et al., 1994; Mendelsohn, 1964; Stark \& Weichselbaum, 2013; Surlin, 1986).

Radio Kerry, like all licenced radio stations in Ireland, has a public service remit as part of its licence agreement. Radio Kerry is therefore the go-to source of breaking news and in-depth analysis of current affairs in the county. This becomes particularly important during general elections, extreme weather events and public crises such as the Covid-19 pandemic where regular and impartial news, information and guidance are paramount. The value of trusted news is even more precious as 'fake news' has proliferated in the digital age and without appropriate regulation.

The Radio Kerry News Editor is cognisant of the demand and need for strong local news journalism as the unique selling point of local radio, however, it is also the most expensive element to produce. The station needs to employ approximately twelve full and part-time staff to gather, edit and deliver quality, trusted and reliable local news, weather, sports and current affairs every day of the year. RTÉ was found to have enviable human resources of roughly three to one compared to the commercial sector. Beat management are aware of the high cost of news content and have adopted the news hub model (McDonald \& Starkey, 2016) with sister station Waterford Local Radio (WLR), since both stations are under the same ownership. The stations also share other departments such as sales and marketing, however the bulk of the on-air output remain distinct.

\section{Audience Intimacy, Connection and Presence}

The second valuable asset working in local radio's favour is knowledge of their audience. The station endeavours to be present with them, primarily on-air, sharing the ebbs and flows of daily life in the county. This also means being visible in the community through outside broadcasts (OBs) at sponsored events usually involving a large, branded mobile studio that brings the station to the public. By showing the station's presence in towns and villages throughout the county, the station is not only fresh in the mind when audience measurement surveys are conducted, but it also presents an opportunity to come to the audience and be part of their lives where they live. As a producer who has worked on many outside broadcasts this author can attest to the positive impact and brand reinforcement a radio station's OB can bring to the local community.

Connecting people is an important function of radio and with recent efforts to remain relevant in an evolving digital world, radio still holds an important place in the lives of Irish people. The flexibility of the medium fosters necessary change in an immensely dynamic, digitalised and audience-focused mediascape. The Beat manager interviewed stated, 'we need to be where they [the audience] are, and these days that increasingly means online'. For Beat this means being present on SNSs which are highly popular amongst younger audiences and allow the station to connect with users via their mobile phones.

Due to its ability to speak to the audience directly, radio simultaneously delivers messages that coalesce individual users into listening communities built around existing social and cultural traits or collective interests. Despite the practices of radio listening and Facebook usage being predominantly solitary activities, radio audiences are aware of shared experiences within wider on-air communities (Douglas, 2004; Michelsen et al., 2019). Although users may only personally know some of the community members, they can identify as part of a wider 'imagined community' (Anderson, 1991) of audience members. The feeling of togetherness can play an important role in supporting individuals to re-affirm and shape their sense of identity (Douglas, 2004; Hilmes, 2007; Moreira, 2019). As an extension of the radio station, the Facebook page can thus serve a similar purpose for radio audiences.

Local radio stations in Ireland have distinct audiences with niche cultural characteristics that set them apart from another station's audience. Examples such as Gaelic sports, natural geographic beauty and celebrities from the locality all generate feelings of pride of place. This is particularly evident in rural areas where the audience is invested in the location and their community of family and friends. Radio Kerry and Beat management are aware that this sense of community is already strong and thus use content tailored specifically to them to engender feelings of togetherness and belonging. This is what makes local radio so successful in Ireland - the ability to create a united community of listeners based on a deep-rooted cultural 
identity. This is central to what has helped local radio remain relevant in the modern digital age and the edge it has over the national and public service stations.

Many of the posts on Beat's Facebook page involve clever memes that the target audience can relate to. As a result Beat's memes are highly popular, receiving strong responses on Facebook. These often involve animals photographed in unusual positions or images that have been altered in some way and are usually accompanied by text which grounds and contextualises the image for the reader. Common memes relate to the general malaise most people feel on Monday morning or the euphoria experienced on Friday. By engendering a sense of shared experience and/or emotion, for example humour, the station is uniting a community of like-minded people who are affected in the same way cognitively and/or emotionally by the meme. This fosters a sense of belonging and togetherness because they 'get' the joke. The remit of the radio producer once involved numerous responsibilities associated with the overall management of a radio programme. Lately the role has expanded to include the management of online content including Facebook and other SNS accounts. Not only does the producer now need to be a curator of high-quality social media content relevant to the target audience, but also consistently maintain a high standard of on-air programming.

\section{On-Air and Online Communities}

Irish radio stations were quick to embrace the possibilities offered by SNSs. Producers and station management could see the benefits of providing increased audience participation and ways to connect with listeners beyond aural broadcasting. Connecting with others was found to be a valuable use and gratification for isolated radio listeners (Armstrong \& Rubin, 1989; Turow, 1974), or to help individuals feel more involved in the community (Avery et al., 1978; Bierig \& Dimmick, 1979), often realised through audience participation facilitated by phone-in programmes that allowed listeners to express their opinions publicly (Crittenden, 1971; Tramer \& Jeffers, 1983). The modern equivalent of this being SNSs of which Facebook remains the most prominent amongst Irish audiences (McMahon, 2019a). Thus, the argument for radio being considered the 'original social medium' (Lapidus, 2018) rings true, such is its legacy as a medium that connects people socially - particularly isolated individuals. Since 2008 Facebook has offered further opportunities for these connections to be made and is a central reason, according to this author, why, radio and Facebook are so compatible. In this age of media convergence, the audience moves to the forefront as power shifts away from media outlets and audience input into media production and associated platforms of communication increases (Jenkins, 2006). New forms of communities have been formed online and continue to evolve and develop over time as older listeners are replaced by younger ones and technology continues to offer widened access to users to connect in new and dynamic ways. However, individuals choose to interact and participate to varying degrees meaning not all are active online participants.

There are a number of levels of online participation from simply 'lurking' in the background up to the highest level of participation. Something akin to Rafaeli's "fully interactive communication", occurs when a user is intellectually or emotionally engaged with a Facebook post (Rafaeli, 1988, p. 119). Posts that create an affective community of individuals with identical or similar feelings related to a topic or memory from their past were found to be the most powerful material used to connect with an audience and thus successful at creating a viral sensation. Some of the best examples of these were found on Beat's page where posts invited users to reminisce about their childhood through memories of toys and games from their youth (McMahon, 2020). This fully interactive deep engagement helps radio stations draw users closer as a community of listeners/online users and promotes loyalty. This comes from having an in-depth knowledge and understanding of the target audience. Radio Kerry is a station very much connected to the people, the county and the communities of Kerry. The management know that in order to gain and maintain the loyalty of the people they need to be a beacon of cultural celebration in the county. This is where radio has been effective in creating a community of like-minded people that share a common bond, as conceptualised by McLuhan as the beating of the 'tribal drum' (McLuhan, 1994).

\section{RADIO KERRY \& BEAT ONLINE COMMUNITIES}

Textual analysis revealed that entertaining and amusing material was the most popular form of content on radio station Facebook pages with postings containing memes, videos, articles, photographs and live in- 
studio video streams particularly successful. Recognising the audience's thirst for local-interest information and knowledge, producers tailor their product accordingly. Sport is an enormously important topic in each and every Irish county and therefore receives a generous share of air time and online posts.

An example of an engaging Facebook post was a photograph of a Kerry Minor Football team which instigated a discussion by asking the audience to try and identify the year the photo was taken and to name as many individuals in the photograph as possible (see McMahon, 2018). A number of people were engaged with the piece; 18 comments were made, including replies, involving 11 individuals, (four of whom were tagged) all contributing to a worthy conversation testing the audience's knowledge of Kerry football. Kerry culture is a sub-set of Irish culture, with many characteristics shared with other regions in Ireland, but with its own unique tastes and histories. By creating fora where users can communicate emotionally and cognitively from anywhere on the planet with other culturally-connected individuals, Radio Kerry is drawing together a transnational audience through micro-cultural public spheres (McGuigan, 2005). The Radio Kerry Facebook page therefore acts as a site of celebration of Kerry culture and, particularly for those living abroad, a space to construct, renegotiate and express their cultural identities.

'Sharing' content instigates conversations with others in a social network while reinforcing identity as a member of a community. In the digital age, this potent phenomenon has created innovative commercial opportunities beyond the scope of traditional marketing. Contemporary media outlets such as radio stations use emotion to develop their audiences into commodifiable communities (Smythe, 1981). In this case, audience satisfaction shifts from a sense of consuming to the feeling of belonging (Wakefield et al., 2017). Nostalgia plays a significant role in the scope of emotions and works as a connector among individuals of the same generation. Beat capitalised on this opportunity, expanding its regional profile by focusing on the appeal of nostalgia to millennials, among other strategic content, thus gaining new 'followers' and extracting economic capital from a blooming digital audience (McMahon, 2016).

Although Radio Kerry is a station that prides itself on its digital presence, Beat by comparison is a more digitally-integrated and socially active radio station. It had by far the most 'followers', interactions and engagement from its audience, of the stations involved in this study. Part of this can be attributed to the audience being largely young 'digital natives' (Palfrey \& Gasser, 2013; Prensky, 2001) for whom digital media has always been a part of their lives. The millennial generation has grown up with social media central to interpersonal communication and emotional expression. However, much credit for the Beat Facebook page's success must go to the production staff who understand their audience intimately and have devised a strategy to engage them emotionally and expand the station's reach in the process.

Two examples of posts by Beat producers illustrate the power of strategic social media posts, a Telebubbies post, and a Betty Spaghetty post, the latter of which experienced substantial viral reach for the station (McMahon, 2020). Millennials would have been in childhood when the Teletubbies (1997) and Betty Spaghetty (1998) toys were released - aimed at the 4-to-8-year-old market. These posts had enormous popularity with individuals of the Irish millennial cohort who share similar memories of their youth. Having these collective memories help them feel part of an imagined, affective community that has awareness of the shared experiences of others, providing a common perception of being a member of a distinct demographic cohort (Strauss \& Howe, 1991). By exploring this specific situation, Beat provoked a cascade effect. The nostalgia and feelings of belonging were reinforced by the affective communication between friends and acquaintances within their social network. As a result, the users expressed emotions with others, some of whom were outside the initial network that follows Beat. Mannheim (1952) posited that the collective experiences that a generational cohort share from growing up through the same local, national and international events shape and mould that group so they react similarly to stimuli and feel closer to one another. In this context, nostalgia is used by Beat as a strategy to engage users emotionally. By generating a strong response from millennial audiences through Facebook posts the station brings users together by building and maintaining social capital (Ellison et al., 2007). This keeps relationships together despite geographical distances and generates bonding social capital which strengthens the strong ties that bind family and close friends (Putnam, 2001).

A knock-on effect occurs when the user feels connected to the radio station as the source of the emotive material. Even if there is no guarantee, there is a considerable likelihood that the user will reward the source by 'liking' and 'following' the Facebook page of the station in order to receive similar content in the future. As 
Maecker et al. write, "Customer engagement... increases the commitment and social identification with the brand as well as the brand community and leads to higher customer retention" (Maecker et al., 2016, p. 136). As a station offering engaging SNS content to their target audience - as the examples above exemplify - Beat are able to build and maintain an audience in a highly competitive market. The radio station has made itself a credible source of cultural material relevant to the target audience and enhanced brand awareness and reputation in the process.

Facebook pages are akin to office watercoolers where individuals gather with other like-minded individuals with whom they share similar tastes, experiences and identities. From this, individuals gain a sense of belonging. By engaging with these online fora users can strengthen the ties between themselves and the station and themselves and other users whether they have offline relationships with those other users or not. The use of Facebook to engage radio audiences is also an example of radio's visualisation, whereby the medium has moved beyond aural only delivery - this is a characteristic of modern radio. This move towards visualistion has enhanced radio's appeal to younger audiences.

The above offers insight into how a radio station can engage with a cohort that has grown up in a multiscreen, multiplatform and multimedia environment where audience attention is difficult to capture and retain. Radio stations targeting young audiences have responded to this by taking advantage of the audience's ubiquitous connectivity, the power of visual imagery, and the viral dissemination and consumption habits of this cohort. This large millennial cohort is key for renewing radio audiences and ensuring the survival of radio stations. Beat targeted millennials using known nostalgic elements as touchpoints to create a sense of belonging between users.

This paper argues that radio station Facebook pages create online social networks, referred to here as quasi-virtual communities, where users interact online in environments that share the same characteristics as traditional geographically-based communities. Numerous authors have presented definitions of community (see Anderson, 1991; Baym, 2010; Delanty, 2010; Gruzd, Wellman, \& Takhteyev, 2011; Hillary, 1955; McMillan \& Chavis, 1986; Rheingold, 2000; Wellman \& Leighton,1979). From these publications eight common features were identified and used as probes in this study to explore whether radio station Facebook pages do create online communities as hypothesised. This was achieved through an online survey with radio station audience members. The characteristics identified were: that a community should have a (1) common shared location; that members should share (2) an emotional connection to other users; that members (3) feel they can influence the community; that members (4) share resources and support; that members have (5) a shared connection with one another; that members (6) feel a sense of belonging to the community; that members (7) have interpersonal relationships with one another; and that members (8) have shared identities.

Overall, the Radio Kerry rating averages for each question were the most positively bias of all stations surveyed meaning they had stronger senses of community than the other audience groups surveyed. This may be explained by the existing sense of community and unity that exists amongst the people of the county of Kerry based on cultural, historical and political characteristics that have shaped the people of the county and their identities. Beat audiences were the next most positively biased community with four positively biased and four negatively biased responses to the eight characteristics, however the rating averages for each criteria were better than those of RTÉ $2 \mathrm{fm}$. The RTÉ $2 \mathrm{fm}$ audience response had four positively biased and four negatively biased criteria for community. This suggests that with a national audience it is harder for producers to generate a sense of community and, the more local the audience is, the tighter the individuals feel as a community.

The radio professionals interviewed felt that their stations' Facebook pages do create a space for their audience to interact and connect with one another, a place where everyone is free and welcome to take part and participate. They also believed that users have a shared connection with one another, with Radio Kerry and Beat this is tied to the geographic region while for RTÉ $2 \mathrm{fm}$ it is their demographic group and shared interest to participate and communicate. The producers also stated that users offer help and support to one another on the Radio Kerry, Beat and Tubridy $2 \mathrm{fm}$ Facebook pages. This often takes the form of advice and the sharing of informational resources, a form of resource sharing that helps bind a community. The Beat staff interviewed felt that the Facebook page does bring some of the users closer together by sharing experiences and advice with one another, though this may be sometimes in a superficial way. The findings suggest that 
the use of computer-mediated communication for interaction between members of society can help strengthen bonds and draw people closer together through social integration. Durkheim argued that the more people interact with one another the more socially integrated they become and therefore the stronger their community and society become (Durkheim, 1984). Thus, there is merit to the argument for online interaction between members whether they have existing offline relationships or not.

Not all radio stations across the Irish Radio Industry have adopted Facebook equally. In fact, the commercial sector was found to be much more aggressive than the public service broadcaster in finding new ways to engage their audience and grow their following through social media strategies and innovation. The disadvantage of national stations is that they offer an agenda of largely national and international news, information and current affairs that can rarely match the local journalism and insight offered by local radio. $R T E ́$, usually considered the standard bearer for quality and innovation in the radio industry, was slow to respond to the opportunities offered to radio by social and other digital media. RTÉ suffered as a result by losing audiences and credibility during a time of enormous economic and technological change in Ireland (McMahon, 2019b). Much of this hesitancy can be attributed to the older age profile of three of the four RTÉ radio stations, with $R T E ́$ $2 \mathrm{fm}$ having the youngest audience.

\section{CONCLUSION \& RECOMMENDATIONS}

Local radio in Ireland is resilient and has survived against economic, technological, socio-cultural and geopolitical threats. It has achieved this not by accident, but by focusing on delivering on its remit to provide high-quality, reputable and locally sourced news, information and cultural content on a daily basis. Local and regional radio in Ireland as a collective has a deep and intimate understanding of its audience and is therefore able to provide highly bespoke material on-air and online that connects with the listener/online user and draws them in. Building on these efforts, and embracing the technology available, local radio has been able to reinforce the community sentiment amongst their listeners by facilitating quasi-virtual online communities. These have helped deliver the content the audience want in visually and emotionally engaging ways. It is this combination of hard work, audience insight and innovation that has offered local radio an edge over the national competition and what will help radio endure for decades to come.

The Irish Radio Industry as a whole must continue to provide quality programming which attracts audiences and, despite also needing to embrace social and digital media, must be strategic in its approach. Commercial radio must continue to be bold and creative while continuing to look for the next opportunity to change radio for the better and attract new audiences. Local radio stations, by virtue of the intimate knowledge of their audiences, are able to do this much more effectively and thus remain competitive and attractive to local audiences. Modern radio production requires a multi-media approach using broadcast content along with a strong digital and social media presence. However, unfortunately the radio industry is harming itself and its revenues by promoting Facebook to its audience. The platform is radio's frenemy.

The ever-present threat of conglomeration is very real in modern radio and with the full economic cost of Covid-19 yet to be realised at the time of writing, local radio will need to continue with its strong efforts if this most trusted voice is to be maintained.

However, local radio and the Irish Radio Industry as a whole will not be able to manage this alone. The industry needs political support and strength from the Broadcasting Authority of Ireland (BAI) and the Irish government not to relax its limits on media ownership. This has been a key plank in warding off the conglomeration of Irish radio. The other threat is purely economic. All radio stations and indigenous media outlets in Ireland, RTÉ included, are in dire need of support due to the siphoning of advertising spend by the digital multinationals. The market is in need of regulation by the government, with the European Commission's support, to protect local media here and throughout the EU.

Changes could involve revenue sharing, taxation, or a combination of these to more fairly redistribute the finite wealth available in the Irish media market and limit the foreign dominance of the likes of Facebook. More importantly, from an audience protection perspective, there are serious issues with how the users' data is gathered, stored, shared and used by Facebook. Increased consumer protection is urgently required. The author also argues for a restructuring and redistribution of the Broadcasting (Television) Receiving Licence revenue to distribute more funds to the commercial sector and help fund the public service content that is so 
vital to society. Radio is an adaptable, hardy medium that has embraced change and new technology to meet the challenges and opportunities of the digital age, it ought to be preserved for the benefit of future generations.

Funding: The author received no financial support for the research and/or authorship of this article.

Declaration of interest: Author declares no competing interest.

Data availability: Data generated or analysed during this study are available from the author on request.

\section{REFERENCES}

Anderson, B. (1991). Imagined communities: Reflections on the origin and spread of nationalism. Verso.

Armstrong, C., \& Rubin, A. (1989). Talk radio as interpersonal communication. Journal of Communication, 39(2), 84-94. https://doi.org/10.1111/j.1460-2466.1989.tb01031.x

Avery, R., Ellis, D., \& Glover, T. (1978). Pattern of communication on talk radio. Journal of Broadcasting, 22(1), 517. https://doi.org/10.1080/08838157809363862

Baym, N. (2010). Personal connections in the digital age. Polity.

Beat. (2021). About Us. Beat 102103. http://www.beat102103.com/about-beat/

Bierig, J., \& Dimmick, J. (1979). The late night radio talk show as interpersonal communication. Journalism Quarterly, 56(1), 92-96. https://doi.org/10.1177/107769907905600114

Chantler, P., \& Stewart, P. (2003). Basic radio journalism. Elsevier.

Chignell, H. (2009). Key concepts in radio studies. Sage.

Core Media/Ignite (2013). Primary reason for listening to radio. MediaVest.

Crittenden, J. (1971). Democratic functions of the open mike radio forum. Public Opinion Quarterly, 35(2), 200210. https://doi.org/10.1086/267891

Crowley, S. (2021). RTÉ to cease radio transmission on DAB network. https://www.rte.ie/news/ireland/2021/0302/1200334-rte-dab-network/

Delanty, G. (2010). Community. Routledge. https://doi.org/10.4324/9780203877050

Douglas, S. (2004). Listening in: Radio and the American Imagination. University of Minnesota Press.

Durkheim, E. (1984). The division of labour in society. Macmillan. https://doi.org/10.1007/978-1-349-17729-5

Ellison, N. B., Steinfield, C., \& Lampe, C. (2007). The benefits of Facebook 'friends': Social capital and college students' use of online social network sites. Journal of Computer-Mediated Communication, 12(4), 11431168. https://doi.org/10.1111/j.1083-6101.2007.00367.x

Gruzd, A., Wellman, B., \& Takhteyev, Y. (2011). Imagining Twitter as an imagined community. American Behavioral Scientist, 55(10), 1294-1318. https://doi.org/10.1177/0002764211409378

Hendy, D. (2000). A political economy of radio in the digital age. Journal of Radio and Audio Media, 7(1), $213-234$. https://doi.org/10.1207/s15506843jrs0701_16

Hillary, G. (1955). Definitions of community: Areas of agreement. Rural Sociology, 20(2), 111-123.

Hilmes, M. (Ed.). (2007). NBC: America's Network. University of California Press. https://doi.org/10.1525/9780520940604

Hofstetter, R., Donovan, M., Klauber, M., Cole, A., Huie, C., \& Yuasa, T. (1994). Political talk radio: A stereotype reconsidered. Political Research Quarterly, 47(2), 467-479. https://doi.org/10.1177/106591299404700212

Independent Broadcasters of Ireland (IBI) (2014). About Us. http://www.ibireland.ie/aboutus

Ipsos MRBI (2011). Joint National Listenership Research. Ipsos MRBI.

Ipsos MRBI (2021a). Joint National Listenership Research. Ipsos/MRBI.

Ipsos MRBI (2021b). JNLR Report: Radio in a Digital World. Ipsos/MRBI.

Jenkins, H. (2006). Convergence culture: Where old and new media collide. New York University Press.

Lapidus, M. (2018). Put the original social network to work. Radio World. https://www.radioworld.com/columns-and-views/put-the-original-social-network-towork

Maecker, O., Barrot, C., \& Becker, J. U. (2016). The effect of social media interactions on customer relationship management. Business Research, 9(1), 133-155. https://doi.org/10.1007/s40685-016-0027-6

Mannheim, K. (1952). The problem of generations. In P. Kecskemeti (Ed.), Essays on the sociology of knowledge: Collected works (Vol. 5, pp. 276-322). Routledge. 
McDonald, K., \& Starkey, G. (2016). Consolidation in the UK commercial radio sector: The impact on newsroom practice of recent changes in regulation, ownership and local content requirement. Radio Journal: International Studies in Broadcast \& Audio Media, 14(1), 123-135. https://doi.org/10.1386/rjao.14.1.123_1

McGee, J. (2018). Time to reassess Ireland's digital advertising market. The Irish Independent. https://www.independent.ie/business/media/time-to-reassess-irelands-digital-advertising-market36666371.html

McGuigan, J. (2005). The cultural public sphere. European Journal of Cultural Studies, 8(4), 427-443. https://doi.org/10.1177/1367549405057827

McLuhan, M. (1994). Understanding media: The extensions of man. Routledge.

McMahon, D. (2014). Radio 2.0: How Facebook is enhancing audience participation for Irish radio audiences. In A. Rospigliosi \& S. Greener (Eds.), Proceedings of the European Conference on Social Media (pp. 665-672). Brighton. https://doi.org/10.1148/radiol.14141860

McMahon, D. (2016). With a little help from my friends: The Irish radio industry's strategic appropriation of social network sites for commercial growth. In Analyzing the strategic role of social networking in firm growth and productivity. IGI Global. https://doi.org/10.4018/978-1-5225-0559-4.ch009

McMahon, D. (2018). The phenomenon of transnational cultural public spheres on Irish radio station Facebook pages: A case study of Radio Kerry. In A. Badenoch \& G. Föllmer (Eds.), Transnationalizing Radio Research: New Approaches to and Old Medium. Bielefeld: Transcript. https://doi.org/10.14361/9783839439135-022

McMahon, D. (2019a). The economic, social \& cultural impact of the social network site Facebook on the Irish radio industry 2011-2016 (PhD Thesis). University of Derby. https://derby.openrepository.com/handle/10545/ 624234

McMahon, D. (2019b). Informed \& educated: When public service radio learns from the commercial radio sector. VIEW Journal of European Television History and Culture, 8(16), 59-73. https://doi.org/10.18146/2213-0969.2019.jethc175

McMahon, D. (2020). Memories of our youth: The viral spread of radio station Facebook posts. Westminster Papers in Communication and Culture, 15(1), 53-67. https://doi.org/10.16997/wpcc.320

McMillan, D., \& Chavis, D. (1986). Sense of community: A definition and theory. Journal of Community Psychology, 14(1), 6-23. https://doi.org/10.1002/1520-6629(198601)14:1<6::AIDJCOP2290140103>3.0.CO;2-I

Mendelsohn, H. (1964). Listening to the radio. In L. A. Dexter (Ed.), People, society, and mass communications. Free Press of Glencoe.

Michelsen, M., Krogh, M., Nielsen, S. K., \& Have, I. (Eds.). (2019). Music radio: Building communities, mediating genres. Bloomsbury Academic. https://doi.org/10.5040/9781501343247

Moreira, P. (2019). Migrant radio, community, and (new) fado: The case of radio ALFA. In M. Michelsen, M. Krogh, S. K. Nielsen, \& I. Have (Eds.), Music radio: Building communities, mediating genres (pp. 31-48). Bloomsbury Academic. https://doi.org/10.5040/9781501343247.0007

Palfrey, J., \& Gasser, U. (2013). Born digital: Understanding the first generation of digital natives. In D. Haugen \& S. Musser (Eds.), The millennial generation. Greenhaven Press.

Prensky, M. (2001). Digital natives, digital immigrants. On the Horizon, 9(5). MCB University Press. https://doi.org/10.1108/10748120110424816

Putnam, R. D. (2001). Bowling alone: The collapse and revival of American community. Simon \& Schuster. https://doi.org/10.1145/358916.361990

Radio Kerry (2021). About Us. https://www.radiokerry.ie/about-us/

Radiocentre (2009). Profitability and localness survey of local commercial radio. Radiocentre.

Radiocentre (2018). Biggest ever audience for commercial radio as ad revenues surge. Radiocentre. https://www.radiocentre.org/biggest-ever-audience-for-commercial-radio-as-ad-revenues-surge-2/

Rafaeli, S. (1988). Interactivity: From new media to communication. In R. P. Hawkins, J. M. Wiemann, \& S. Pingree (Eds.), Advancing communication science: Merging mass and interpersonal processes. Sage.

RAJAR (2020). RAJAR data release - quarter 1, 2020. Radio Joint Audience Research. https://www.rajar.co.uk/docs/news/RAJAR_DataRelease_InfographicQ12020.pdf

Reuters Institute (2018). Reuters institute digital news report. http://www.ibireland.ie/radio-takes-top-spot-inthe-reuters-news-report/ 
Rheingold, H. (2000). The virtual community: Homesteading on the electronic frontier. MIT Press. https://doi.org/10.7551/mitpress/7105.001.0001

Slattery, L. (2021). Denis O’Brien's Communicorp agrees €100m-plus sale to Bauer Media Audio. The Irish Times. $\quad$ https://www.irishtimes.com/business/media-and-marketing/denis-o-brien-s-communicorpagrees-100m-plus-sale-to-bauer-media-audio-1.4494816

Smythe, D. W. (1981). Dependency road: communications, capitalism, consciousness, and Canada. Ablex Publishing.

Stark, B., \& Weichselbaum, P. (2013). What attracts listeners to Web radio? A case study from Germany. Radio Journal: International Studies in Broadcast \& Audio Media, 11(2), 185-202. https://doi.org/10.1386/rjao.11.2.185_1

Starkey, G. (2011). Local radio, going global. Palgrave MacMillan. https://doi.org/10.1057/9780230347991

Starkey, G., \& Crisell, A. (2009). Radio journalism. https://www.doi.org/10.4135/9781446214350

Strauss, W., \& Howe, N. (1991). Generations: The history of America's future, 1584 to 2069. William Morrow.

Surlin, S. (1986). Uses of Jamaican talk radio. Journal of Broadcasting \& Electronic Media, 30(4), 459-466. https://doi.org/10.1080/08838158609386637

Tramer, H., \& Jeffers, L. W. (1983). Talk radio - Forum and companion. Journal of Broadcasting, 27(3), $297-300$. https://doi.org/10.1080/08838158309386496

Turow, J. (1974). Talk show radio as interpersonal communication. Journal of Broadcasting, 18(2), 171-179. https://doi.org/10.1080/08838157409363732

Wakefield, J., Sani, F., Madhok, V., Norbury, M., Dugard, P., Gabbanelli, C., \& Poggesi, F. (2017). The relationship between group identification and satisfaction with life in a cross-cultural community sample. Journal of Happiness Studies, 18(3), 785-807. https://doi.org/10.1007/s10902-016-9735-z

Waterson, J. (2020). Scores of local radio stations to lose local programming. The Guardian. https://www.theguardian.com/media/2020/may/27/local-radio-regional-stations-england-bauerrebranding-national-network

Wellman, B., \& Leighton, B. (1979). Networks, neighborhoods, and communities: Approaches to the study of the community question. Urban Affairs Review, 14(3), 363-390. https://doi.org/10.1177/107808747901400305

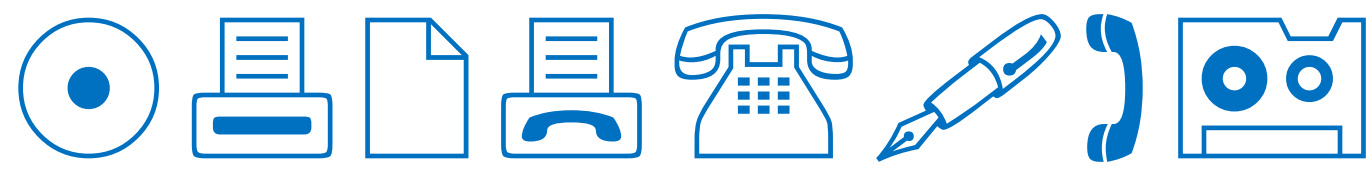

